\title{
Dimensions of Service Quality Satisfaction Community at the Village Government Office
}

\author{
Moh. Hudi Setyobakti ${ }^{1}$, Wahyuning Murniati ${ }^{2}$ \\ Departement of Accounting, STIE Widya Gama Lumajang ${ }^{12}$ \\ Email: hudisetyobakti@gmail.com
}

https://doi.org/10.30741/wiga.v10i1.456

\begin{tabular}{ll} 
A R T I C LE I N F O & A B S T R A C T \\
\cline { 3 - 3 } $\begin{array}{l}\text { Date of entry: } \\
\text { 9 January 2020 }\end{array}$ & $\begin{array}{l}\text { Enhancement public service is one goal of the village setting for the } \\
\text { community. Therefore, this study analyzed the correlation between the } \\
\text { Revision Date: }\end{array}$ \\
10 February 2020 & $\begin{array}{l}\text { sample in this study was } 83 \text { respondents, Lumajang community who use the } \\
\text { services of the village offices, which were analyzed using multiple linear } \\
\text { Date Received: }\end{array}$ \\
16 March 2020 & $\begin{array}{l}\text { satisfaction significantly. The coefficient of determination in this study was } \\
\text { g7.8\%, it can do that only requires empathy Lumajang community village } \\
\text { government in the ministry. But the village government should not rule out } \\
\text { other dimensions of quality of service, because they have laws that regulate } \\
\text { their work to the public. }\end{array}$
\end{tabular}

Keywords: Service Quality, Satisfaction, Village Government

\section{INTRODUCTION}

The village government, as a government agency based in the village, has the authority and obligation to carry out governmental functions in the village. Governing keep functions that include providing services to the community, given the village government in particular government service is an obligation that must be carried out to the community in the form of good service.

Act No. 6 of 2014 states that one purpose of the setting of the village is to improve public services for the community. Services referred to herein have the two (2) dimensions, namely; (A) The services regarding the function of the village authority based rights Permendesa origin as No. 1 in 2015, such as health care, education; and (b) Administrative services citizenship. The understanding that rural service improvement innovation will contribute to an increase in public satisfaction related to rural services. But the reality of public service conditions varies between villages. Act No. 6 of 2014 which emphasizes the principles of recognition and subsidiarity, it should seek their village government good service to the independence of the village."

Service quality by Parasuraman is "how far the difference between reality and expectations of customers for the services they receive or obtain" (WAHAB, 2017), Therefore the dimensions of service quality in the village government include; tangible (physical facilities), reliability (reliability), responsiveness(Responsiveness), assurance (assurance) and empathy (empathy). Tangible dimension capabilities include physical infrastructure provided by the village 
government to the public. As for the dimensions of reliability (reliability) include the ability to provide the promised services with accurate and reliable. Dimensions responsiveness (responsiveness) includes all the wisdom to provide prompt service to the public, do not let people wait without a clear reason that causes a negative perception in the quality of service. Dimensions assurance (guarantee) covers the knowledge and friendliness as well as the ability to spontaneously carry out tasks which can ensure good performance, so that engenders trust and confidence. Furthermore, to the dimensions of empathy (empathy) is realized by giving attention to the individual or personal to customers and seeks to understand the consumer.

\section{RESEARCH METHODS}

This type of research is quantitative survey approach, with the goal of explanatory nature to explain the causal relationship between one variable to another variable through hypothesis testing. The population of this research is that a society Lumajang customer or user of the services of the village administration office, where the number of villages in Lumajang as many as 198 villages. Purposive sampling method used for sampling with the following criteria; (1)Villagers Lumajang, (2) Representation of four (4) areas that reflect the characteristics of different villages, (3) Any representation of the area will be sampled three (3) Village drawn at random, and (4) Each village, participants include as many as 10 (ten) of respondents. Based on the above criteria, then obtained 83 respond as samples in this study. The analysis uses multiple linear regression method to test the instruments carried out at the beginning of the analysis process. Further testing is done on the assumption of classical regression equation which followed on testing hypothesis, either partially or simultaneously.

\section{RESULTS AND DISCUSSION}

Testing instrument explained that the questionnaire survey results are valid and reliable; it can be said that the questionnaire can solicit the opinions of respondents in the study. Nextdetermination coefficient of 0.778 , which means $77.8 \%$ variable Lumajang community satisfaction can be explained by the dimensions of satisfaction in this study and the remaining $22.2 \%$ is influenced by other variables not examined in this study. Regression model of this study, is; $\mathrm{Y}=2,6+0,112 \mathrm{X}_{1}+$ $0,112 \mathrm{X}_{2}+0,033 \mathrm{X}_{3}+0,187 \mathrm{X}_{4}+0,383 \mathrm{X}_{5}$. Where; $\mathrm{Y}=$ satisfaction of community, $\mathrm{X} 1$ : $\quad$ tangible, $\mathrm{X} 2$ : reliability, $\mathrm{X} 3$ : irresponsiveness, $\mathrm{X} 4$ : assurance, $\mathrm{X} 5$ : empathy.

The first hypothesis states that the dimensions of the physical evidence of significant effect partially to the satisfaction of the people in the village government in Lumajang. Description of statements in the questionnaire for this hypothesis consists of (1) Available service counter, (2) The number of service outlets is sufficient, (3) There are complaints from the public service counter, (4) There are waiting rooms were clean and comfortable, (5) The layout of the office space neat and clean, (6) Adequate office facilities and can support the performance of village, (7) There are facilities such as restrooms, parking lots and other facilities that make visitors feel comfortable in the village service office, (8) Adequate parking conditions so that people feel safe to linger in the village to take care of each interest, (9) Conditions decent village office building (10) There is a community hall that can be used for meetings or discussions. From the survey results, it is known that the majority of respondents expressed approval on every statement for this variable. This shows that the village government offices in Lumajang generally adequate physical, in accordance with Regulation No. 18 the Year 2018. Basically, tangible variables are one of the important things in the fulfilment of the public service. All the facilities are available should be able to support the quality of service that will improve public satisfaction Lumajang. The analysis showed that the independent variables in the form of a physical form not significant effect on the dependent variable in the form of community satisfaction. This indicates that the physical state of the building is not one thing that can satisfy community-related Lumajang village government 
services. But whether it should be ruled out. The answer is of course not, because, like the previously discussed that the provision of the physical form of the village government office has been set at Permendagri 18 of the year 2018. Therefore, it is an obligation to the village government to provide all facilities associated with a physical form such as service counters, toilets and all facilities that support the performance of services and community needs.

The second hypothesis is dimension reliability is partially affected significantly to the satisfaction of the community the village government in Lumajang.DESCRIPTION statement in questionnaires for this variable is comprised of the following statements; (1)Office services start at a predetermined time, (2) Service counter opened and closed in accordance with the provisions of working hours, (3) Counters of complaints opened and closed in accordance with the provisions of working hours, (4) Service counter clerk worked diligently, (5) The clerk of complaints receive public complaints wisely, carefully and can provide exact solutions, (6) Stewardship of the file is done on time, (7) The cost of file management in accordance with the provisions of the existing, (8) Officers worked according to the procedure, (9) Services provided optimalAnd (10) The ability of officers in terms of solving problems is a very good community, Based on the results of the survey respondents note that the approval rate is high enough is known of the majority answered agreed for each item in the questionnaire statement related to the variable reliability. While based on the results of hypothesis testing found that the reliability of variables not significant effect on public satisfaction in Lumajang. Reliability variable indicates the quality of the village in solving the problems that brought the people to the village administration. As people all Lumajang is personal not understand about administrative matters related to village government, therefore, is needed a reliable village in village government services. However, analysis shows that the reliability of variables not significant effect on the dependent variable, satisfaction of the people. Therefore it can be concluded that the public Lumajang device reliability is not too prioritize work to ensure satisfactory service. On the other side is a guide job if it leads to reliability, in which a working device is supposed to always improve the quality of their work to serve the community.

The third hypothesis states that dimensions of responsiveness are partially affected significantly to the satisfaction of the community the village government in Lumajang.DESCRIPTION This variable declaration consists of the following statement; (1)Public complaints officer can serve any complaints swiftly given society, (2) Officers can carefully explain all the files related to the requirements in terms of service village, (3) If there is a shortage of personnel with the requirements then carefully explained the matter clearly and patiently, (4) Service very friendly village clerk, (5) Each community issues addressed by either, (6) The village can complete each service with alacrity (7) Every complaint has always responded according to existing procedures, (8) The village quickly in resolving the existing problems. From the results of the questionnaire collection note that the approval rate of respondents high enough is known of the majority answered agreed for each item in the questionnaire statement related to the variable responsiveness. While the hypothesis test result indicates that the variable responsiveness not significant effect on public satisfaction in Lumajang. Variable responsiveness is one thing that should be owned by the village, especially in the district of Lumjang. This is because most people Lumajang are people who do not understand the bureaucracy related. Responsiveness of the village will be everything into community problems into a solution that can help people. The analysis shows that public satisfaction was not significantly affected by the variable reliability of the village. However,

The fourth hypothesis in this study stated that dimensional partial effect significant guarantee the satisfaction of society the village government in Lumajang, Based on the description of the item stated in a questionnaire consisting of statements (1) There is a guarantee that any complaints will be addressed properly in accordance with the procedure, (2) Each of the public interest is guaranteed to be resolved properly and correctly, (3) People feel every problem can be solved with good, (4) There is clarity related to the process of resolving community issues, (5) There is a guaranteed turnaround time file from the village clerk, (6) The services provided are always 
promising thing is certain, It is known that the majority of respondents stated its agreement with each statement. Guarantee or assurance is a sense that people feel safe or secure for any problems that they bring to the office of the village administration. It can be felt if the village can complete the problem the community well. The results of the analysis state that the public Lumajang not really need it. Known with variable guarantees not significant effect on the dependent variable, namely the satisfaction of the public.

The fifth hypothesis which states that dimension empathy is partially affected significantly to the satisfaction of the community the village government in Lumajang, Based on the description of the item stated in a questionnaire consisting of statements (1) The village receives public complaints patiently, (2) The village received a friendly society, (3) The village tried to work with all my heart for any public purposes can be completed on time, (4) The village tried to make any public complaints can be resolved properly, (5) Village officials to provide advice regarding any community issues patiently and in accordance with the procedure, (6 The village help each handling files with the patient, ( 7 The village received a complaint patiently, It is known that the majority of respondents stated its agreement with each statement. Variable empathy is the only independent variables that significantly influence people's satisfaction variables. From this, it can be concluded that the public Lumajang will be satisfied when the village government to empathize with their problems. However, not all independent variables in this study do not necessarily have to be met by the village government and in accordance Permendagri 18 the Year 2018, already discussed related to everything that must be met by the village government. Therefore, by adhering to the rule, the village government should be able to keep improving the quality of public services better.

Hypothesis Six states that the quality dimension is simultaneously significant on the public satisfaction of village governments in Lumajang. Based on the description of the item stated in a questionnaire consisting of statements (1) Community satisfied with the service at the village office, (2) Society considers that any arrangement can be resolved properly and in a short time, (3) Society is always taken when complaints related to matters involving the village, (4) Services of the village were friendly and patient to make people more comfortable, (5) Society does not hesitate in reporting any problems related to village, (6) Satisfaction in every file management make the public believe the performance of village, (7) Office environment clean and tidy to make people comfortable doing the activities in the village, It is known that the majority of respondents stated its agreement with each statement. The results showed that five of these variables affect the satisfaction of society simultaneously, which means that this third hypothesis is accepted or proved to be true.

\section{CONCLUSION}

This research resulted in the conclusion that dimension village government service quality is influenced partially by empathy variable only. While simultaneously, all independent variables in this study affect the dimensional quality of government services in the village are significant. Lumajang shows that society Lumajang requires empathy from the village of village government office-related services, but in spite of it, the government should pay attention to the fifth village dimensions of satisfaction in this study.

\section{REFERENCE}

Donny, S. (2016). Pengaruh Lima Dimensi Kualitas Pelayanan Terhadap Kepuasan Anggota Koperasi Susu Warga Mulya Purwobinangun Pakem Sleman (Vol. 3). Https://Doi.Org/Https://Doi.Org/10.3929/Ethz-B-000238666

Haryanto, E. I. 2303-1174. (2013). Kualitas Layanan, Fasilitas Dan Harga Pengaruhnya Terhadap 
Kepuasan Pengguna Jasa Layanan Pada Kantor Samsat Manado. Jurnal Emba.

Nilasari, E., \& Istiatin. (2015). Pengaruh Kualitas Pelayanan Terhadap Kepuasan Konsumen Pada Dealer Pt. Ramayana Motor Sukoharjo. Jurnal Paradigma.

Puspitasari, N. L. P., \& Bendesa, I. K. G. (2016). Analisis Kualitas Pelayanan Publik Di Badan Pelayanan Perijinan Terpadu Kabupaten Badung. E-Jurnal Ekonomi Dan Bisnis Universitas Udayana 5.1 (2016).

Rezha, F., Rochmah, S., \& Siswidiyanto. (2013). Analisis Pengaruh Kualitas Pelayanan Publik Terhadap Kepuasan Masyarakat (Studi Tentang Pelayanan Perekaman Kartu Tanda Penduduk Elektronik (E-Ktp) Di Kota Depok). Administrasi Publik.

Riyadi, S., Hermawan, A., \& Sumarwan, U. (2017). Kepuasan Masyarakat Terhadap Kualitas Pelayanan Kantor Pertanahan Kabupaten Indramayu. Jurnal Ilmu Keluarga Dan Konsumen. Https://Doi.Org/10.24156/Jikk.2015.8.1.49

Wahab, W. (2017). Pengaruh Kualitas Pelayanan Terhadap Kepuasan Nasabah Pegadaian Syariah Di Kota Pekanbaru. Al-Masraf: Jurnal Lembaga Keuangan Dan Perbankan, 2(1), $27-41$. Retrieved From Https://Journal.Febi.Uinib.Ac.Id/Index.Php/Almasraf/Article/View/89 